\title{
Project-Based Learning: Enhancing EFL Students' Speaking Skill through Vlog
}

\author{
Wienda Febriyanti Nugroho ${ }^{1}$, Mirjam Anugerahwati ${ }^{1}$ \\ ${ }^{1}$ English Language Teaching-Universitas Negeri Malang
}

\begin{tabular}{l}
\hline \hline INFO ARTIKEL \\
\hline Riwayat Artikel: \\
Diterima: 04-02-2019 \\
Disetujui: 20-08-2019 \\
\hline
\end{tabular}

\section{Kata kunci:}

project-based learning, speaking skill;

vlog;

pembelajaran berbasis proyek; keterampilan berbicara; $v \log$

\section{Alamat Korespondensi: \\ Wienda Febriyanti Nugroho \\ Pendidikan Bahasa Inggris \\ Universitas Negeri Malang \\ Jalan Semarang 5 Malang \\ E-mail: wienfn@gmail.com}

\section{ABSTRAK}

\begin{abstract}
The purpose of this classroom action research is to enhance the students' speaking skill using Project-Based Learning through Vlog and looking at their speaking performance in the teaching learning process using PBL through Vlog. Eleven students of vocational students in Indonesia were taken as research subject exposed to the treatment of PBL through Vlog in one cycle. The result of this study showed that after the students were taught by using PBL through Vlog, the eleven students successfully met the criteria of success. The use of PBL through Vlog enhanced the students' fluency, grammatical accuracy, pronunciation, vocabulary, and content.
\end{abstract}

\begin{abstract}
Abstrak: Tujuan dari penelitian tindakan kelas ini adalah keterampilan berbicara menggunakan Project-Based Learning melalui pembelajaran dan proses belajar mengajar menggunakan PBL melalui Vlogs. Sebelas siswa siswa kejuruan di Indonesia diambil sebagai subjek penelitian untuk pengobatan PBL melalui Vlog dalam satu siklus. Hasil penelitian ini menunjukkan bahwa siswa terpenuhi oleh kriteria kesuksesan. Penggunaan PBL melalui Vlog meningkatkan kelancaran siswa, akurasi tata bahasa, pengucapan, kosa kata, dan konten.
\end{abstract}

English is a foreign language in Indonesia; therefore, it is rarely used in country. For instance; employee uses Indonesian in the office; housewife uses her mother tongue to communicate with her sons or daughters, and Indonesian students use English only at school. They use it at school because English is a compulsory subject and it is stated in Regulation of the Minister of National Education of the Republic of Indonesia Number 20 Year 2016 About Primary and Secondary Level Graduate Competence Standards. In the previous curriculum or Kurikulum Tingkat Satuan Pendidikan (school-based curriculum), vocational school students only focused on grammar and vocabulary. It was a traditional instruction. To sum up, speaking is a hard skill to learn especially for EFL learners.

Speaking is the skill that will be the variable of this research for some reasons. The first is the unsatisfactory scores of the students of accounting program in Vocational High School (Sekolah Menengah Kejuruan) in Madiun. The second, the students are afraid to speak up with their peers. The third, the students do not have high confidence and low motivation. The last, they get difficulty when they have a conversation with their peers or teacher. When they are asked to tell the topic, they do not speak fluently. So that's why this skill should be built up beside the other three language skills.

In addition, speaking is also the essential skill to communicate with others. (Nunan, 1995) argues that the important factor of studying language is speaking when the language is a natural language or target language and the achievement is quantified by the skill of language students to complete discussion in the language being studied. Based on the statement above, speaking is a crucial skill to communicate, express and give reactions when the students have a discussion and dialogue with others.

The researcher, who is the English teacher of the accounting class, chose speaking for the research because of the unsatisfactory score of the speaking skill produced by the tenth graders in vocational high school in Madiun. The researcher identifies the obstacles of the students when they study English; they get difficulty to speak English such as when they want to answer the teacher's question as they do not have enough diction and vocabulary, get confused to pronounce, and forget what they say. It means they find it difficult to produce words in English. On the other hand, students should master some aspects of speaking as English as a Foreign Language such as proficiency, accuracy, and comprehensibility. (Heaton, 1988) proposes that the three aspects need to educate our students to speak English namely eloquence, precision, and understanding. Based on the statement above, it can be concluded that there are three important aspects that should be mastered by students to speak English. 
The next problem is that the previous teacher used a traditional way and it is still teacher-centred which caused students unable to focus and to be interested in English. The teacher did not give the opportunity to the students and the teacher only focused on grammar. As a good teacher, the learning-teaching process should be learner-centred and the teacher is a facilitator for the students. (Kumaravadivelu, 2006) claims that the teacher has a role as a facilitator. The teacher must assist students in comprehending and understanding the purpose of language as a method, communication, and principle in the classroom discussion.

Having utilized a speaking test, observation and interview, the initial test showed that in terms of speaking, the researcher asked the students to tell narrative text then they had to record it using Whatsapp video. They got some obstacles; for instance, they made wrong pronunciation, and they employed wrong pattern (grammar) although they had got guidance from the teacher through the youtube video and they were not fluent. It looked like that they rarely practiced speaking in junior high school. Vygotsky (Williams \& Burden, 1997) states that a child follows an adult's example and bit by bit build up the ability in this case is speaking-to do specific tasks without help. Thus, in this case, the teacher should give certain examples related to the topic. For example: how to pronounce the words and how to tell a good story.

After the initial test, the researcher observed the students' videos. The topic was about telling a narrative in monolog. The recording videos showed that the students were shy, only smile and they hesitated to speak. They said that they cannot practice well as they get confused about what they should say. Based on that observation, the researcher summed up that they got difficulty for saying something in English as they rarely practiced their speaking.

In terms of interview, the researcher employed some questions to seek the additional problem why students did not want to practice their English. The students felt lazy to study English as their previous teacher only taught them about pattern which was taken from student worksheet. They said that they rarely practiced their speaking because the previous teacher only asked them to do exercises in the student worksheet to be submitted. So, their daily activity at the previous school (in junior high school) only finished exercises in the student worksheet without any feedback from their teacher. (Combe \& Codreanu, 2016; Moore, Nicholls, Strengers, Maller, \& Horne, 2017) says that in a learning context, both positive and negative feedback is crucial. Beneficial feedback shows learners their current level of performance and lets them know what they need to do to gain a higher level. It can be concluded that feedback is essential and the teacher should give feedback in teaching learning process to increase the students' level.

Based on the researcher's previous study, some of the tenth grade of accounting students failed to do a speaking test because from eleven students, only two students were able to pass the speaking test. They were able to reach the minimum Passing Criteria (Kriteria Ketuntasan Minimal/ KKM) (70). Both of them were good to practice their speaking, to pronounce and to speak fluent enough. During the speaking test, the students got confused about what they should say related to the topic. They needed 15 minutes for preparation. After that, they took a recording and they asked some words related to the topic. They did wrong pronunciation, incorrect grammar and they were not fluent. To sum up all of the problems above, speaking is certainly difficult for tenth grade of the accounting students. So, the researcher as the teacher in tenth grade of the accounting class should be able to find the best solution for how she can enhance her students' speaking skill.

The researcher realizes that speaking is essential for her students as it can help them to face their future and it benefits them to engage in the industry or factory. However, to learn speaking, the students face some obstacles. Finally, the researcher decided to find activities, which are appropriate for the students' need, enjoyable, interesting, motivating and able to get the students to involve and help them to overcome their speaking problem. The researcher conducts classroom action research, which employs Project based Video using Vlog application. Below is the detailed information, why the researcher prefers to choose Project Based Learning and Vlog.

Vlog refers to a type of blog in which most or all of the content is in video form. The students can use this application through their Smartphone. This application is easy to access for the students nowadays. The students can make a video then upload their video on YouTube on their blog. Vlog is a combination of video and blog (blog itself is a mix of web and log). Blogs can be used for writing and Vlog can be used for communication (Anil, 2016). In line with (Combe \& Codreanu, 2016), Vlogs have the potential to build up digital literacy and speaking skills in front of a camera and promote publication (speech acts and gestures, enhancing the final media product before posting it, adding text, and emoticons which illustrate speech acts). Based on the statement above, Vlog can help students to build up their speaking and the students' digital literacy.

Being a part of digital literacy, Vlog can contribute to students' speaking skill improvements by making them post their public speaking videos. Thus, Vlog is essential for students in terms of appropriate technology employment practice both technically and practically (Medlock, Spires, \& Kerkhoff, 2017; Thang et al., 2014). Further, it exposes students to various ways of anticipating challenges in their learning process, making them critical thinkers. Critical thinking has been a concern of the $21^{\text {st }}$ century learning, along with communication, collaboration and creativity; all of which will be put into practice through Vlog making. (Rakhmanina \& Kusumaningrum, 2017) conducted experimental research. From their research finding, it is shown that teaching and learning speaking using Video blogging strategy to Law Faculty students is more effective than using Expository strategy. 
(Bunjan \& Suppasetseree, 2017) also conduct quasi-experimental research. Their result finding shows that the students who learned the Video Blog Based Role Play lessons significantly improved their English oral communication skills. Research conducted by (Anil, 2016) focuses on the attitudes of the respondents towards using VLOG to improve their English communicative skills. The conclusion drawn by the researchers is that the involvement of Vlog enhances and effective to the student's general speaking progress. The treatment results in specific progress.

All of the reviewed previous studies were done in either experimental research or survey. One of them was conducted in Indonesia. That is why the researcher is very confident to conduct her research in classroom action research. She is sure that the results of her research will be important for the existing further studies. Besides, none of the analysis in previous studies above is in the form of Project Based Learning. In addition, there is small-scale research that has been done which focuses on the use of Vlog in Vocational high school as the most research had been conducted in University.

(Coffey, 2015) claims that Project-based learning is a teaching approach which involves students in continuous, collaborative real-world investigations. Projects are arranged around a driving question, and students take part in a variety of tasks that make efforts to counter this question meaningfully. In line with Terry et al (2011 cited in (Fathurrohman, 2015), Project Based Learning is a model for classroom activities that are initially teacher-centred then it changes into student-centered. It can be concluded that project-based is innovative learning to involve the students in learning process; students can get meaningful activity and students are able to show their original project.

Projects-Based learning (PBL) refers to an instructional strategy which focuses learner-centred classroom practice without applying traditional method or "teacher-centred" (Harun, 2006). Project-based Learning assists students build up skills for living in a knowledge-based and the highest technological society. Resolving highly complex obstacles requires students to have both fundamental skills (listening, reading, speaking and writing) and Digital Age skills. With the skills combinations, students become directors and managers of their learning through a skillful teacher's guiding and mentoring. Project-based learning brings real-life context and technology to the curriculum through the project. Students are encouraged to become independent workers, critical thinkers, and lifelong learners.

From the explanation above, the researcher decides PBL by (Harun, 2006) as it is based on the students' characteristics and the students' problem faced in the researcher's school. According to (Harun, 2006), there are the six steps in PJBL. The steps are starting with the essential question, designing the steps, arranging project's schedule, project completion by teacher's monitoring, assessing the outcome, and the last step is evaluating the project.

Considerable studies have confirmed that Project Based Learning is effective for EFL Learning. (Rochmahwati, 2016) has got the successful result that the use of project-based learning significantly influences the students' speaking ability. In line with (Supe \& Kaupuzs, 2015), using project work may help to make the language used in the class real and active, keep the pupils' attention and make the learning process more exciting. It is shown that Project-Based Learning is the effective way to improve the students' speaking ability.

There are some factors that influence speaking through Project Based Learning model such as the enhancement activation of the students' background knowledge, given peer response to other friends' project, group work and the real-life topic given. This project made students have critical thinking. Project-Based Learning model can enhance the students' speaking skill and influences some factors of the students' speaking skill in terms of grammar, vocabulary, fluency, and comprehension and their confidence as well. It can be implied that project based learning model is very useful in teaching speaking. Therefore, the researchers assured that Project based Learning is effective to enhance the students' speaking skills and they proposed for the English teachers to employ Project-based Learning as an alternative model to deal with the obstacle in the teaching and learning process of speaking. Based on the background above, the research questions is how can project-based Vlog enhance the speaking skill of the tenth graders accounting program of vocational high school in Madiun?

\section{METHOD}

The aim of this research was to investigate the speaking skill enhancement of the tenth graders accounting program of vocational school in Madiun through project-based learning using Vlog. The research design of this study was classroom action research. The action research employed in this study followed (Kemmis, McTaggart, \& Nixon, 2013) model. Each cycle consists of four stages: planning, implementing, observing, and reflecting. The research was conducted in a cycle compromised five meetings included the final test. The participants were 11 students who study in vocational high school in Madiun. This research utilized speaking rubric for assessing students' speaking performance by (Brown \& Lee, 2015; O'malley \& Pierce, 1996). The data were collected by assigning them to tell the folklore individual in a monolog way used in project based learning through Vlog. Additionally, we prepared the criteria of success (see table 1). 
Table 1. Criteria of Success

\begin{tabular}{cll}
\hline No & \multicolumn{1}{c}{ Criteria of Success } & \multicolumn{1}{c}{ Instruments } \\
\hline 1 & $\begin{array}{l}\text { All of the students get score at least 70 for the } \\
\text { speaking performance }\end{array}$ & $\begin{array}{l}\text { A speaking } \\
\text { performance test }\end{array}$ \\
\hline 2 & $\begin{array}{l}\text { At least } 50 \% \text { of students could pass the } \\
\text { minimum passing criteria }\end{array}$ & $\begin{array}{l}\text { A speaking } \\
\text { performance test }\end{array}$ \\
\hline
\end{tabular}

\section{FINDING}

\section{Enhancement of the Students' Speaking Skill}

The performance of student's speaking skills was gained by assigning them to tell the folklore in a monolog way used in project based learning through vlog. The students' performance was assessed upon their fluency, grammatical accuracy, pronunciation, vocabulary and content.

The students gained more after learning speaking by using project based learning (PBL) through Vlog. In the initial test study 3 students were at good level, 5 students were at fair level and 3 students were at poor level in average. After the students were taught by using PBL through vlog, all of students (11 students) were at good level. The comparison between scores in the initial test and the final test result can be seen in figure 1 .

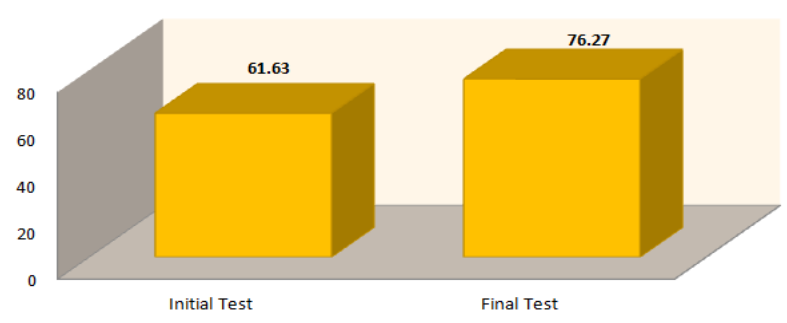

\section{Figure 1. The Comparison between Scores of Initial Test and Final Test}

Based on the result of the comparison of the students' speaking scores in initial test and final test, it was found that the use of PBL through vlog increased the students' speaking scores. In the initial test the average of the students' scores in speaking was 61.63 and the average of scores in the final test after the action was 76. 27. Based on the result of final test, the students' speaking skill improved. The test result for fluency, grammatical accuracy, pronunciation, vocabulary (word choice) and content can be seen in figure 2 .

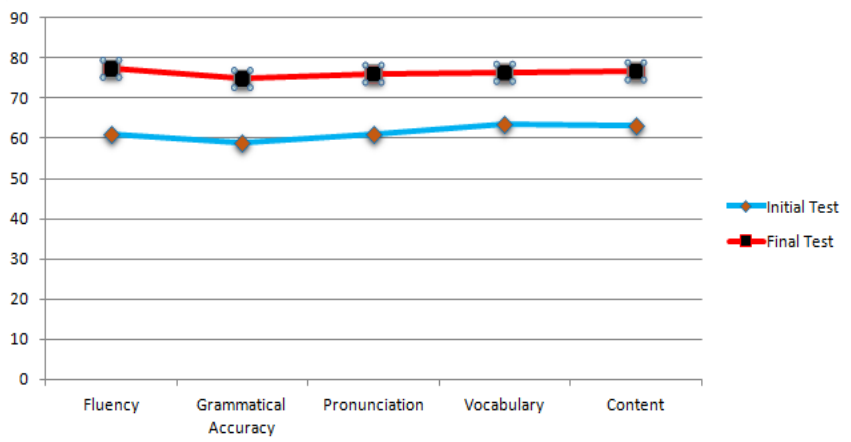

Figure 3. The Result of the Strategy's Implementation

In terms of fluency, there were 11 students at good level in the final test while in initial test there were 3 students at good level, 5 students were at fair level and 3 students were at poor level. The average score in the final test was 77.36 while the average score in initial test was 61.09. 
In terms of grammatical Accuracy, there were 11 students at good level in the final test while in the initial test there were 4 students at good level, 3 students at fair level and 3 students at poor level. Totally the average score in the final test was 74.81 while in the initial test was 59.09 .

In terms of pronunciation, there were 11 students at good level in the final test while in the initial test there were 3 students at good level, 5 students were at fair level and 3 students were at poor level. Totally the average score in the final test was 76.09 while in the initial test was 61.18 .

In terms of vocabulary/ word choice, there were 11 students at good level in the final test while in the initial test there were 3 students at good level, 6 students were at fair level and 2 students were at poor level. Totally the average score in the final test was 76.36 while in the initial test was 63.45 .

In terms of content, there were 11 students at good level in the final test while in the initial test there were 3 students at good level, 6 students at fair level and 2 students at poor level. Totally the average score in the final test was 76.72 while in the average score in the initial test was 63.36 .

In conclusion, the criteria of success have been achieved in that every student increased their score. In other words, the use of project based learning through Vlog has enhanced the speaking skill of the tenth grade students of vocational high school in Madiun.

\section{The Implementation of Project Based Learning through Vlog}

The implementation of Project Based Learning through Vlog, were concluded in six steps. Here are the details

Step 1. Asking the students to decide the folklore to be put in the Vlog The researcher asked the students to decide the folklore which provided by the researcher. There were 4 titles. The students were interested to choose as all of the folklores were from their area. After choosing one folklore, they tried to read it and comprehend the folklore. They also tried to understand the generic structure of their folklore.

Step 2. Assigning the students to reconstruct the folklore in their own words in the Vlog The researcher asked the students to reconstruct the folklore using their own words. They reconstructed their folklore individually. They also divided the folklore based on the generic structure of narrative texts.

Step 3. Revising the students' folklore draft before being recorded into Vlog

The researcher with collaborator checked and gave suggestion to the students' folklore. At the first time, they made many mistakes but after revising the draft, they made it in a good way. They checked it all after they received it from the researcher. Then they wrote again and finally they submitted again to the researcher.

Step 4. Asking the students to practice telling the folklore through Vlog

The students started to practice telling the folklore in the class after getting feedback from the researcher. Then they continued it at home. They practiced telling the folklore in a monolog way like a reporter. After they were sure with their pronunciation, they started to record their project using vlog application on their cell phone.

Step 5. Asking to design the project through the Vlog application In this step, the researcher asked the students to design their video using Vlog application's features. Before doing this step, the researcher gave guidance first how to design and edit their video using vlog application. They were enthusiastic and motivated when the teacher explained it. They feel happy to learn English using Vlog application and they understood well about the features.

Step 6. Asking the students to submit the folklore In the last step, the students should submit their completed project. They submit it to the researcher and the researcher with the collaborator assessed their project using a speaking rubric.

\section{DISCUSSION}

\section{Enhancement of the Students' Speaking Skill}

Enhancing of the students' skill through project based vlog was successfully achieved. The improvement can be seen from their individual score and also the average score in every aspect. The students' individual score showed that the lowest score was 73.4 and the highest score was 80.2 in the real performance. Moreover, their average score also improve to 76.27 . Hence, applying project based-learning is the effective way to improve the students' speaking skill as it applies learner-centered classroom practice (Harun, 2006). In addition, the positive and negative feedback is crucial as feedback can increase the students' level (Moore et al., 2017; Rochmahwati, 2016). The findings of this research are similar to the findings of several studies that PBL can improve students' speaking abilities (Combe \& Codreanu, 2016; Rochmahwati, 2016). The finding showed that implementing project can improve the students' speaking skill significantly. 
In this research, it was proven that appropriate technology (vlog) can build up the students' speaking skill. In line with (Combe \& Codreanu, 2016), vlogs have the potential to develop digital literacy and speaking skill in front of a camera and encourage publication. In addition Vlog is an essential technology for students' speaking skill improvement (Medlock et al., 2017; Thang et al., 2014). This research showed the result that using project based-learning through vlog had achieved significantly. The students' speaking skill improved, at least, in six aspects including fluency, grammatical accuracy, pronunciation, vocabulary, and content.

\section{The Implementation of Project Based Learning through Vlog}

Teaching speaking through the implementation of using project based vlog made the students more active to speak English as speaking is the important skill which should be built up first then the other skills. It is line to (Spratt \& Williams, 2005) that speaking is a beneficial ability. (Nunan, 1995; Sani, Manurung, Suswanto, 2018) also strengthen it that speaking is the essential skill to communicate with others.

The implementation of PBL using vlog in improving students' speaking skill consists of some points to consider. They are fluency, grammatical accuracy, pronunciation, vocabulary and content. It is an analytic scoring rubric for speaking adapted by (Brown \& Lee, 2015; O'malley \& Pierce, 1996). The students gained more after learning speaking by using PBL through vlog. The students were involved in five meeting including the final test.

In the first meeting the researcher led the students to the topic. The researcher allowed the students to choose their folklore. The researcher (the teacher) is a facilitator and it focused in students-centered. The teacher must assist students in comprehending and understanding the purpose of language (Kumaravadivelu, 2006). In addition, Terry et all (2011 cited in (Fathurrohman, 2015)) stated that Implementing PBL is an innovative learning as it involves students in learning process and students are able to show their original project. The researcher only guided the students. After choosing one folklore, they tried to read it and comprehend the folklore. (Kumaravadivelu, 2006) confirms that the teacher should reduce the mismatches between teacher intention and learner interpretation.

In the second meeting, the students started to reconstruct the folklore using their own words. It is based on the researcher's guidance and example through slide presentation. This is also supported by Vygotsky (cited in (Williams \& Burden, 1997)) by explaining that the teacher should give a certain example. Practically students did all of the tasks based on the researcher's guidance and example. After they finished reconstructing the folklore, the students should submit the folklore and the researcher checked their folklore with the collaborator using speaking rubric. The researcher gave feedback and correction. (Harmer, 2007) stated that giving appropriate correction can helps students' in their learning process. Then, students should revise and submit the folklore.

In the third meeting, the researcher explains to get vlog, how to use vlog and how to make video using vlog as vlog is an appropriate and essential technology for the students' speaking skill. In line with, (Anil, 2016) vlog can be used for communication. Experimental research which is conducted by (Rakhmanina \& Kusumaningrum, 2017) showed that teaching and learning speaking using video blogging strategy is effective.

In the fourth meeting, the students performed in the front of the class to do short presentation related their project. This activity made students more confidence to share their experience making project based vlog. It is supported by (Supe \& Kaupuzs, 2015), they conducted experimental research that PBL is an effective way to improve the students' speaking skill and make the learning process more exciting.

The last meeting is final test. They had to make project based vlog. They had to make it for 3 minutes. They did it in a monolog way like a reporter. Based on the result of final test, the implementation of project based learning through vlog had achieved and it was fulfill the criteria of success in this research.

\section{CONCLUSION}

Based on the research findings, it is concluded that the implementation of project based learning through Vlog in teaching speaking improves the students speaking skill in fluency, grammatical accuracy, pronunciation, vocabulary and content. This enhancement could be proved by the students' speaking achievement and the score gained by the students. The score of the speaking test has fulfilled the criteria of success. All lower students got the score greater than 70 and all higher students got the score greater than 70, and also all students got score greater than 70. In addition, the students were actively participated; more motivated and they felt happy in teaching and learning process.

The learning model that has been proven to be able to enhance students' speaking achievement include the following steps: (1) asking the students to decide the folklore to be put in the vlog; (2) assigning the students to reconstruct the folklore in their own words in the vlog; (3) revising the students' folklore draft before being recorded into vlog; (4) asking the students to practice telling the folklore through vlog; (5) asking to design the project through the vlog application; (6) asking the students to submit the folklore. Step one can be done in the first meeting. Step two to six are in the second to the fourth meeting. The use of 
project based-learning through vlog can enhance the students' fluency, grammatical accuracy, pronunciation, vocabulary and content. The students' can grasp the information faster and feel confident.

\section{REFERENCES}

Anil, B. (2016). Top-Up Students Second Language Talk Time through Vlogs. Indonesian Journal of EFL and Linguistics, 1(2), 129-143. https://doi.org/http://dx.doi.org/10.21462/ijefll.v1i2.9

Brown, H., \& Lee, H. (2015). Teaching by Principles: An Interactive Approach to Language Pedagogy (Fourth Edi). London: White Palms: Pearson Education Inc.

Bunjan, A., \& Suppasetseree, S. (2017). The Video Blog Based Role Play Lessons to Enhance English Oral Communication Skills for Tourism Students. International Journal of Educational Administration, 9(1), 1-16.

Combe, C., \& Codreanu, T. (2016). Vlogging: A New Channel for Language Learning and Intercultural Exchanges. ResearchPublishing. Net.

Fathurrohman, M. (2015). Model-model Pembelajaran Inovatif. Yogyakarta: Ar-Ruzz Media.

Harmer, J. (2007). The Practice of English Language Learning (Fourth Edi). Harlow: Pearson Education, Inc.

Harun, Y. (2006). Project-Based Learning handbook "Educating the Millennial Learner'. Kuala Lumpur: Educational Technology Division Ministry of Education.

Heaton, J. B. (1988). Writing English Language Tests (New ed). London \& New York: Longman.

Kemmis, S., McTaggart, R., \& Nixon, R. (2013). The Action Research Planner: Doing Critical Participatory Action Research. Springer Science \& Business Media.

Kumaravadivelu, B. (2006). Understanding Language Teaching: From Method to Postmethod. Routledge.

Medlock, P., Spires, H., \& Kerkhoff, S. (2017). Digital Literacy for the 21 st Century. Hershey: Igi Global.

Moore, T., Nicholls, L., Strengers, Y., Maller, C., \& Horne, R. (2017). Benefits and challenges of energy efficient social housing. Energy Procedia, 121, 300-307.

Nunan, D. (1995). Language Teaching Technology: A Textbook for Teachers. London: Phoenix ELT.

O'malley, J. M., \& Pierce, L. V. (1996). Authentic Assessment for English Language Learners: Practical Approaches for teachers. Addison-Wesley Publishing Company New York.

Rakhmanina, L., \& Kusumaningrum, D. (2017). The Effectiveness Of Video Blogging In Teaching Speaking Viewed from Students'Learning Motivation. Proceedings of ISELT FBS Universitas Negeri Padang, 5, 27-34.

Rochmahwati, P. (2016). Project-based learning to Raise Students' Speaking Ability: its' Effect and Implementation (a mix Method Research in Speaking II Subject at STAIN Ponorogo). Kodifikasia, 9(1), 199-222.

Sani, R. A., Manurung, S.R., \& Suswanto, H. (2018). Penelitian Pendidikan. Tangerang: Tira Smart.

Supe, O., \& Kaupuzs, A. (2015). The Effectiveness Of Project-Based Learning In The Acquisition Of English As A Foreign Language. 2(2015). https://doi.org/https://doi.org/10.17770/sie2015vol2.458

Thang, S. M., Sim, L. Y., Mahmud, N., Lin, L. K., Zabidi, N. A., \& Ismail, K. (2014). Enhancing $21^{\text {st }}$ Century Learning Skills Via Digital Storytelling: Voices of Malaysian Teachers and Undergraduates. Procedia-Social and Behavioral Sciences, 118, 489-494. https://doi.org/https://doi.org/10.1016/j.sbspro.2014.02.06

Williams, M., \& Burden, R. L. (1997). Psychology for Language Teachers: A Social Constructivist Approach. ERIC. 